\title{
Learning Style Preferences Based on Class and Gender
}

\author{
Farman', Arbain², Fitriyani Hali3 \\ DOI:10.35445/alishlah.v13i1.368
}

Info Artikel Abstract

Keywords:

Learning style

VARK

Modalities

Unimodal

Multimodal

Kata kunci:

Gaya belajar

VARK

Modalitas

Unimodal

Multimodal

\begin{abstract}
This study aims to identify and describe students' learning style preferences in the mathematics education study program based on class and gender. This research is a type of quantitative research with a descriptive design that describes the percentage of learning style trends in mathematics education students based on class and gender and then draws conclusions on the percentage of learning style preference. The sample of this research was 44 students of the Mathematics Education study program at USN Kolaka. The instrument used in this study was a questionnaire containing 16 questions related to VARK learning styles (Visual, Auditorial, Read/Write, Kinesthetic). The VARK questionnaire instrument used is a standard questionnaire adapted from The VARK Questionnaire Version 7.1. The results showed that students' learning styles had a multimodal preference(23\% bimodal, $27 \%$ trimodal, $18 \%$ quadmodal). When viewed from class, class A and class B also have a multimodal preference where ARK is the most dominant preference for class A while class B's most dominant preferences are AK and VARK. In terms of gender, women had a multimodal preference ( $7 \%$ bimodal, $33 \%$ trimodal and $13 \%$ quadmodal) and men had a multimodal preference (31\% bimodal, $24 \%$ trimodal and $21 \%$ quadmodal).
\end{abstract}

\begin{abstract}
Abstrak
Tujuan penelitian ini adalah untuk mengidentifikasi dan mendeskripsikan preferensi gaya belajar mahasiswa program studi pendidikan matematikaberdasarkan kelas dan jenis kelamin. Penelitian ini merupakan jenis penelitian kuantitatif dengan desain deskriptif yang mendeskripsikan persentase kecenderungan gaya belajar mahasiswa pendidikan matematika berdasarkan kelas dan jenis kelamin kemudian menarik kesimpulan terhadap persentase kecenderungan gaya belajar tersebut. Sampel penelitian ini adalah mahasiswa program studi Pendidikan Matematika USN Kolaka sebanyak 44 orang. Instrumen yang digunakan dalam penelitian ini berupa angket yang berisi 16 pertanyaan terkait gaya belajar VARK (Visual, Auditorial, Read/Write, Kinestetik). Instrumen kuisioner VARK yang digunakan merupakan kuisioner standar yang diambil dari The VARK Questionnaire Version 7.1. Hasil penelitian menunjukkan bahwa gaya belajar mahasiswa memiliki kecenderungan multimodal (23\% bimodal, $27 \%$ trimodal, $18 \%$ quadmodal). Jika ditinjau dari kelas, kelas A dan kelas B juga memiliki kecenderungan multimodal dimana
\end{abstract}

\footnotetext{
${ }^{1}$ Universitas Sembilanbelas November Kolaka, Kolaka, Indonesia.

Email: farman.math@yahoo.co.id

${ }_{2}$ Universitas Sembilanbelas November Kolaka, Kolaka, Indonesia.

Email: abughazwanalhasan@gmail.com

3 Universitas Sembilanbelas November Kolaka, Kolaka, Indonesia.

Email: fitriyanihali@gmail.com
} 
ARK sebagai preferensi paling dominan untuk kelas A sedangkan preferensi paling dominan untuk kelas B adalah AK dan VARK. Jika ditinjau dari jenis kelamin, perempuan memiliki kecenderungan multimodal (7\% bimodal, 33\% trimodal dan $13 \%$ quadmodal) dan laki laki-laki memiliki kecenderungan multimodal (31\% bimodal, $24 \%$ trimodal dan $21 \%$ quadmodal).

\section{PENDAHULUAN}

Perguruan tinggi berperan penting sebagai pondasi pembangunan dalam menentukan arah kemajuan suatu bangsa dalam di sektor pendidikan. Dalam menjalankan fungsi tersebut, dosen memegang peranan yang sangat vital. Oleh karena itu, diperlukan sosok dosen yang profesional, yaitu dosen yang mampu memenuhi standar kompetensi jabatannya sehingga mampu melaksanakan tugas jabatannya secara efektif, efisien dan bertanggung jawab. Dosen merupakan komponen dalam perguruan tinggi yang dalam melaksanakan tugasnya bersentuhan langsung dengan mahasiswa. Oleh karena itu, seorang dosen dituntut untuk memberikan pelayanan yang prima kepada mahasiswanya agar tujuan dari perguruan tinggi sebagai pencetak sumber daya manusia yang berkualitas dapat terwujud.

Namun tidak jarang terdapat beberapa pendidik/dosen masih belum mampu memberikan pelayanan yang maksimal dalam kegiatan pembelajaran yang dilaksanakannnya. Sebagai comtoh, pembelajaran matematika di kelas lebih mengacu pada perangkat pembelajaran guru yang tidak sesuai, dan proses belajar mengajar yang kurang optimal dengan metode, pendekatan, dan evaluasi (Farman, 2020). Pembelajaran yang dilakukan oleh pedidik masih bersifat teacher centered, dimana pendidik masih terlibat secara aktif dan mendominasi sehingga siswa kurang memiliki peran dalam pembelajaran (Hali et al., 2020). Bahkan mayoritas pembelajaran di kelas berfokus pada kemampuan siswa hanya untuk mengingat dan menyimpan berbagai informasi tanpa memperhatikan informasi yang diingat untuk menghubungkannya dengan lingkungan keluarga dan dalam kehidupan sehari-hari. Situasi ini mengakibatkan lulusan secara teoritis cerdas, tetapi mereka kurang mampu menerapkan ilmu yang mereka miliki di lingkungan (Chairuddin \& Farman, 2019). Penyebab lain adalah bentuk pembelajaran yang dilaksanakan guru masih kurang memperhatikan perbedaan setiap peserta didik dan pembelajaran yang kurang efektif terhadap kebutuhan dan karakteristik peserta didik (Sulisawati et al., 2019).

Pembelajaran yang efektif adalah pembelajaran yang sesuai dengan gaya belajar siswa. Wehrwein et al. (2007) mengungkapkan bahwa salah satu cara untuk meningkatkan kualitas pembelajaran adalah dengan mengadaptasi pendekatan pembelajaran yang memenuhi kecenderungan gaya belajar siswa. Melalui informasi tentang karakteristik gaya belajar peseta didik di awal pembelajaran, pendidik dapat mengembangkan model/metode pembelajaran yang sesuai dengan gaya belajar peserta didik. Hal ini sangat perlu dilakukan karena dapat mempermudah pendidik dalam menyampaikan pengetahuan kepada peserta didik. Begitu pula tehadap peserta didik, kondisi tersebut akan memberikan rasa nyaman dan senang terhadap pembelajaran karena sesuai dengan kemampuan dan karakteristiknya. Tidak ada pelajaran yang sulit, jika pendidik melaksanakan pembelajaran yang sesuai dengan gaya belajar peserta didik (Sari, 2014). Dengan demikian informasi tentang gaya belajar dapat membantu pendidik dalam mengidentifikasi dan memecahkan masalah belajar di antara peserta didik dan membantu peserta didik menjadi pembelajar yang lebih efektif.

Gaya belajar atau yang biasa disebut dengan modalitas belajar adalah berbagai cara yang digunakan sistem otak untuk mengakses informasi dan menciptakan pengalaman. Kecepatan dan kekuatan otak dalam mengolah dan menyimpan informasi dalam memori memiliki pengaruh dalam terjadinya proses penyampaian (modalitas) informasi saat informasi tersebut masuk melalui indera (Jahring \& Chairuddin, 2019). Kesadaran akan preferensi gaya belajar memiliki impilikasi yang bermanfaat terhadap pembelajaran. Pendidik dapat menggunakan pengetahuan ini untuk memfasilitasi pembelajaran dengan memilih model pembelajaran yang tepat sesuai dengan gaya 
belajar peserta didik. Selain itu, siswa sendiri dapat menggunakan informasi ini untuk mengubah kebiasaan belajarnya dengan melakukan cara belajar yang sesuai sehingga mampu meningkatkan prestasi akademiknya (Urval et al., 2014; Sinha et al., 2013). Modalitas belajar merupakan salah satu karakteristik yang harus diketahui oleh pendidik sebelum melaksanakan kegiatan pembelajaran (Sulisawati et al., 2019).

Faktanya masih banyak pendidik yang belum memanfaatkan informasi gaya belajar peserta didik sebagai dukungan untuk meningkatkan pembelajaran di kelas. Urval et al., (2014) mengungkapkan bahwa pemanfaatan pengetahuan ini secara formal untuk meningkatkan proses pengajaran atau lingkungan belajar hampir tidak dilakukan. Fenomena ini sejalan dengan kondisi di Prodi Pendidikan Matematika Universitas Sembilanbelas November Kolaka (USN Kolaka). Hasil observasi menunjukkan bahwa penggunaan model pembelajaran dalam perkuliahan yang dilaksanakan dosen belum merujuk dan sesuai dengan gaya belajar mahasiswa. Pelaksanaan perkuliahan didominasi penggunaan perangkat pembelajaran (silabus, SAP, bahan ajar, dll) yang hampir sama dari tahun ketahun dan kurangnya inovasi-inovasi dalam pembelajaran yang memanfaatkan teknologi sebagai media pembelajaran. Hal ini dapat menyebabkan pembelajaran kurang maksimal yang berpengaruh terhadap prestasi mahasiswa. Hal ini tampak pada nilai capaian mahasiswa pendidikan matematika angkatan 2017 pada matakuliah aljabar linear yang masih kurang maksimal. Sebanyak 44 mahasiswa, yang mencapai nilai kategori baik $(3,0)$ hanya 16 (36\%)mahasiswa, selebihnya 28 (67\%) mahasiswa menadapat nilai di bawah kategori baik. Oleh karena itu, sangat penting untuk mengetahui gaya belajar mahasiswa/peserta didik. Kebutuhan informasi gaya belajar semakin penting untuk program pendidikan guru karena calon guru akan menjadi model bagi siswanya (Güryay, 2016).

Ada banyak metode atau alat yang tersedia untuk menilai gaya belajar, dengan masingmasing metode menawarkan pandangan yang berbeda tentang preferensi gaya belajar. Metode yang digunakan berupa kecenderungan gaya belajar berdasarkan modalitas indera. Fleming mendefinisikan empat modalitas belajar yaitu visual (V), auditory (A), read/write (R), dan kinestetik (K) yang lebih dikenal dengan VARK. Fleming menyatakan siswa dapat menggunakan model itu untuk mengidentifikasi gaya belajar yang mereka sukai dan, pada gilirannya, memaksimalkan pembelajaran mereka dengan berfokus pada mode yang paling bermanfaat. VARK mengkategorikan pembelajaran siswa berdasarkan sistem saraf yang disukai saat menerima informasi (Choudhary et al., 2011). Peserta didik visual lebih suka belajar melalui alat bantu visual yang merepresentasikan ide baik dengan grafik, bagan, diagram, atau simbol. Peserta didik auditori belajar dengan mendengarkan melalui ceramah, diskusi, atau mendengarkan kaset. Peserta didik read/ write lebih suka kegiatan belajar melalui kegiatan membaca dan menulis. Peserta didik kinestetik lebih tertarik belajar melalui pengalaman diantaranya bergerak, eksplorasi aktif dunia, kerja proyek atau melakukan eksperimen (Stephenson, 2019).

Beberapa ahli dan peneliti menunjukkan peran penting adanya pengetahuan modalitas belajar VARK dan penggunaanya. (Karim et al., 2019) menyatakan bahwa siswa mampu belajar secara efektif selama guru memberikan perpaduan antara aktivitas visual (V), auditory (A), read /write (R)dan kinestetik (K). Terdapat variasi gaya belajar antara mahasiswa pada kelas berbeda, ada kelas yang gaya belajar sama dan ada juga yang gaya belajar antar kelasnya berbeda (Sari, 2014) . Tidak terdapat perbedaan yang signifikan preferensi modalitas belajar VARK antara laki-laki dan perempuan (Marzo, 2016). Tetapi penelitian Wehrwein et al., (2007) menyatakan bahwa laki-laki dan perempuan memiliki preferensi gaya belajar VARK yang berbeda. Penelitian Rahmawati et al. (2018) menyatakan bahwa terdapat hubungan antara gaya belajar terhadap IPK mahasiswa.

Kajian ini berbeda dengan penelitian-penelitian sebelumnya. Penelitian ini dilakukan untuk memperoleh informasi kecenderungan gaya belajar siswa baik dari pemetaan kelas maupun dari jenis kelamin pada mahasiswa pendidikan matematika. Pada penelitian Jahring \& Chairuddin (2019) dan Wehrwein et al., (2007)hanya mengkaji gaya belajar mahasiswa berdasarkan jenis kelamin. Sari (2014) melakukan penelitian gaya belajar berdasarkan pembagian kelas. Marzo (2016) melakukan 
penelitian gaya belajar berdasarkan pembagian kelas dan gender pada mahasiswa kedokteran.Penelitian ini akan menjadi acuan bagi mahasiswa untuk menyesuaikan gaya belajarnya, juga menjadi referensi bagi dosen untuk mengembangkan pembelajaran sesuai dengan gaya belajar mahasiswa.

Identifikasi dan analisis gaya belajar mahasiswa diperlukan dan penting dilakukan oleh dosen sebagai penggerak utama terjadinya kegiatan pembelajaran. Melalui informasi gaya belajar mahasiswa, dosen diharapkan dapat semakin mengoptimalkan kegiatan pembelajaran dengan menetapkan pendekatan pembelajaran yang sesuai dengan materi dan gaya belajar yang diinginkan oleh mahasiswa. Dengan demikian tujuan dalam penelitian ini yaitu untuk mengidentifikasi dan mendeskripsikan preferensi/kecenderungan gaya belajar VARK (Visual, Auditorial, Read/Write, Kinestetik) berdasarkan kelas dan jenis kelamin.

\section{METODE}

Penelitian ini merupakan jenis penelitian kuantitatif yang menggunakan desain deskriptif. Penelitian ini dikategorikan penelitian kuantitatif karena data penelitian berupa angka-angka dan analisis menggunakan statistik (Sugiyono, 2011). Penelitian deskriptif dilakukan dengan tujuan untuk mendiskripsikan atau menggambarkan fenomena yang berkenaan dengan masalah dan unit yang diteliti. Dalam penelitian deskriptif fakta-fakta hasil penelitian disajikan apa adanya. Penelitian deskriptif dimaksudkan untuk mendiskripsikan variabel yang diteliti tanpa dilakukan analisis dalam keterkaitannya dengan variabel lainnya (Mulyadi, 2011). Penelitian deskriptif kuantitatif dalam penelitian ini adalah penelitian yang mendeskripsikan persentase kecenderungan gaya belajar mahasiswa pendidikan matematika angkatan 2017 berdasarkan kelas dan jenis kelamin kemudian menarik kesimpulan terhadap persentase kecenderungan gaya belajar tersebut.

Penelitian dilakukan di Program Studi pendidikan Matematika FKIP USN Kolaka. Populasi dalam penelitian ini adalah seluruh mahasiswa pendidikan matematika angkatan 2017 yang berjumlah 44 orang. Teknik pengambilan sampel dalam penelitian ini menggunakan nonprobability sampling bentuk sampling jenuh. Sugiyono (2011) menyatakan bahwa sampling jenuh adalah teknik penentuan sampel jika seluruh anggota populasi digunakan sebagai sampel. Hal ini dilakukan untuk memberikan generalisasi dengan kesalahan yang relatif kecil. Sampel terdiri atas dua kelas dengan jumlah masing-masing kelas adalah 22 mahasiwa.

Teknik pengumpulan data yang digunakan dalam penelitian ini adalah dengan penyebaran angket. Instrumen yang digunakan dalam penelitian ini berupa angket yang berisi pernyantaan yang digunakan untuk memperoleh informasi penelitian tentang preferensi/kecenderungan gaya belajar VARK yang disukai oleh subyek penelitian. Instrumen kuisioner VARK yang digunakan merupakan angket standar yang diambil dari The VARK Questionnaire Version 7.1 pada laman www.varklearn.com. Angket terdiri atas 16 pernyataan dengan 4 pilihan jawaban yang mewakili indikator VARK. Angket ini telah divalidasi dan uji reliabel dengannilaivaliditas dengan pearson product moment adalah 0,266 dan nilai reliabilitas dengan cronbach's alpha adalah 0,803. Hasilnya menunjukkan bahwa angket gaya belajar VARK dinyatakan valid dan reliabel (Lisiswanti, 2014). Angket disusun dalam bentuk google form kemudian diberikan kepada subjek melalui WhatApp grup kelas. Subjek/responden dapat memilih lebih dari satu pilihan untuk mengidentifikasi preferensi berbagai gaya belajar.

Teknik analisis data dalam penelitian ini menggunakan analisis deskriptif berdasarkan pada analisis kecenderungan gaya belajar dalam bentuk persentase. Analisis kecenderungan gaya belajar setiap responden diperoleh melalui rekapitulasi data angket. Analisis yang dilakukan berupa persentase kecenderungan gaya belajar secara keseluruhan dari mahasiswa, persentase kecenderungan gaya belajar berdasarkan kelas mahasiswa dan persentase kecenderungan gaya belajar berdasarkan jenis kelamin mahasiswa. Persentase ditentukan melalui pembagian jumlah responden yang memiliki/menyukai gaya belajar tertentu dengan jumlah total responden. Adapun analisis kecenderungan gaya belajar setiap responden dilakukan dengan cara membandingkan 4 
(empat) pilihan gaya belajar responden yang terdiri atas visual (V), auditorial (A), read/write (R) dan kinestetik (K). Penarikan kesimpulan dilakukan dengan kriteria sebagai berikut:

1. Jika terdapat satu pilihan gaya belajar terbanyakdari semua pilihan gaya belajar, maka disimpulkan mahasiswa cenderung dominan pada pilihan gaya belajar terbanyak tersebut.

2. Jika terdapat dua pilihan atau lebih gaya belajar, maka mahasiswa tersebut tergolong pada pada gabungan kedua atau lebih gaya belajar tersebut.

3. Jika terdapat dua pilihan dari dua kelompok gaya belajar yang memiliki selisih 1, maka mahasiswa tersebut tergolong pada pada gabungan kedua gaya belajar tersebut.

Kecenderungan gaya belajar dikelompokkan berdasarkan pilihan mahasiswa. Mahasiswa yang hanya memilih satu opsi berarti gaya belajarnya cenderung unimodal $(\mathrm{V}, \mathrm{A}, \mathrm{R}, \mathrm{K})$ dan mahasiswa yang memilih lebih dari satu opsi berarti gaya belajarnya cenderung multimodal yang terdiri atas bimodal (responden memilih dua opsi gaya belajar), trimodal (responden memilih tiga opsi gaya belajar), dan quadmodal (responden memilih empat opsi gaya belajar). Data kecenderungan ini kemudian dideskripsikan dalam bentuk tabel dan grafik.

\section{HASIL PENELITIAN DAN PEMBAHASAN}

Berdasarkan hasil analisis data menunjukkan bahwa sebanyak 14 mahasiswa (32\%) angkatan 2017 Prodi Pendidikan Matematika USN Kolaka memiliki kecenderungan unimodal (V, A, $\mathrm{R}, \mathrm{K}$ ) dan sebanyak 30 mahasiswa (68\%) memiliki kecenderungan multimodal (bimodal, trimodal, quadmodal). Gaya belajar mahasiswa Prodi Pendidikan Matematika USN Kolaka angkatan 2017 secara umum disajikan pada Gambar 1.

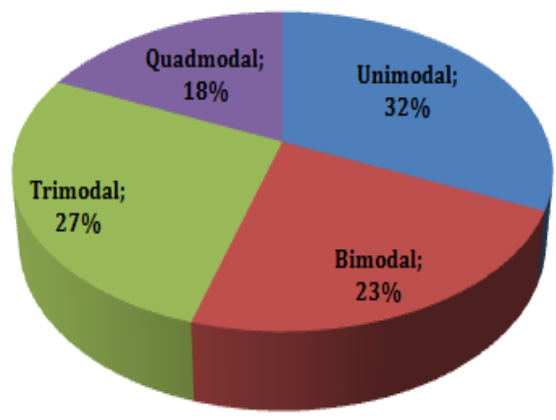

\section{Gambar 1. Distribusi gaya belajar mahasiswa}

Gambar 1 memberikan informasi bahwa distribusi multimodal masing-masing menunjukkan sebanyak 10 mahasiswa (23\%) memiliki kecenderungan modalitas belajar bimodal, sebanyak 12 mahasiswa (27\%) memiliki kecenderungan modalitas belajar trimodal dan 8 mahasiswa (18\%) memiliki kecenderungan modalitas belajar quadmodal. Dengan demikian dapat dikatakan bahwa gaya belajar mahasiswa Prodi Pendidikan Matematika USN Kolaka angkatan 2017 mempunyai kecenderungan multimodal.

\section{Gaya Belajar Berdasarkan Pembagian Kelas}

Pada tahun 2017, mahasiswa Prodi Pendidikan Matematika USN Kolaka terdiri dari dua kelas yaitu Kelas A dan Kelas B. Masing-masing kelas memiliki jumlah mahasiswa 22 untuk kelas A dan 22 untuk kelas B. Preferensi gaya belajar mahasiswa untuk kedua kelas tersebut ditampilkan pada Tabel 1.

Tabel 1. Preferensi Gaya Belajar Berdasarkan Kelas

\begin{tabular}{lcccc}
\hline \hline & \multicolumn{2}{c}{ Gaya Belajar } & Kelas A (\%) & Kelas B (\%) \\
\hline \multirow{3}{*}{ Unimodal } & $\mathrm{V}$ & $\mathrm{O}(\mathrm{0} \%)$ & $1(4 \%)$ \\
\cline { 2 - 4 } & & $\mathrm{A}$ & $3(14 \%)$ & $3(14 \%)$ \\
\cline { 2 - 4 } & & $\mathrm{R}$ & $\mathrm{O}(0 \%)$ & $2(9 \%)$ \\
\cline { 2 - 4 } & $\mathrm{K}$ & $4(18 \%)$ & $1(4 \%)$ \\
\hline Multimodal & Bimodal & $\mathrm{VA}$ & $2(9 \%)$ & $\mathrm{O}(0 \%)$ \\
\hline
\end{tabular}




\begin{tabular}{lllcc}
\hline & AR & $1(4 \%)$ & $0(0 \%)$ \\
\cline { 2 - 4 } & AK & $3(14 \%)$ & $4(18 \%)$ \\
\cline { 3 - 5 } Trimodal & VAR & O(0\%) & $2(9 \%)$ \\
\cline { 3 - 5 } & VAK & O(0\%) & $2(9 \%)$ \\
\cline { 2 - 4 } & ARK & $5(23 \%)$ & $3(14 \%)$ \\
\cline { 2 - 4 } & Quadmodal & VARK & $4(18 \%)$ & $4(18 \%)$ \\
\hline & Jumlah & $22(100 \%)$ & $22(100 \%)$ \\
\hline \hline
\end{tabular}

Tabel 1 menunjukkan bahwa mahasiswa angkatan 2017 Program Studi Pendidikan Matematika USN Kolaka pada kelas A mempunyai unimodal sebanyak 7 mahasiswa (32\%) dan multimodal sebanyak 15 mahasiswa (68\%). Sedangkan kelas B mempunyai unimodal sebanyak 7 mahasiswa (32\%) dan multimodal sebanyak 15 mahasiswa (68\%). Mahasiswa kelas A memiliki gaya belajar auditorial, read/write, kinestetik (ARK) sebagai preferensi paling dominan. Mahasiswa kelas B memiliki gaya belajar auditori, kinestetik (AK) dan visual, auditorial, read/write, kinestetik (VARK) sebagai preferensi paling dominan. Dengan demikian dapat disimpulkan bahwa mahasiswa angkatan 2017 Prodi Pendidikan Matematika pada kelas A memiliki modalitas multimodal dan kelas B juga memiliki modalitas multimodal.

Hasil yang diperoleh bahwa modalitas kelas A dan B memiliki modalitas yang sama yaitu multimodal, sehingga perlu digunakan pembelajaran yang tepat dan sesuai dengan gaya belajar tersebut. Hal ini sejalan dengan penelitian Sari (2014) yang menyatakan bahwa terdapat gaya belajar mahasiswa yang sama pada dua kelas berbeda dengan tingkat yang sama. Namun pada angkatan dengan kelas berbeda tidak selalu memiliki gaya belajar yang sama. Sebagaimana penelitian Marzo (2016) bahwa tidak terdapat perbedaan variasi gaya belajar antar siswa mahasiswa dengan kelas berbeda. Hal ini disebabkan oleh perbedaan karakteristik gaya belajar yang terdapat dalam suatu kelas.

\section{Gaya Belajar Berdasarkan Jenis Kelamin}

Mahasiswa angkatan 2017 Prodi Pendidikan Matematika yang berjumlah 44 mahasiswa terdiri dari 15 laki-laki dan 29 perempuan. Penelitian ini juga mengkaji tentang perbedaan gaya belajar berdasarkan jenis kelamin, sebagaimana Choudhary et al., (2011) menyebutkan bahwa jenis kelamin merupakan salah satu faktor yang mempengaruhi gaya belajar siswa selain usia, prestasi akademik, pemrosesan otak, budaya dan pemikiran kreatif. Preferensi gaya belajar mahasiswa berdasarkan jenis kelamin disajikan pada Tabel 2.

Tabel 2. Preferensi Gaya Belajar Berdasarkan Jenis Kelamin

\begin{tabular}{|c|c|c|c|c|}
\hline \multicolumn{3}{|c|}{ Gaya Belajar } & Laki-laki (\%) & Perempuan (\%) \\
\hline \multirow{4}{*}{ Unimodal } & & $\mathrm{V}$ & $\mathrm{O}(0 \%)$ & $1(3,45 \%)$ \\
\hline & & A & $3(20 \%)$ & $3(10,34 \%)$ \\
\hline & & $\mathrm{R}$ & $1(6,67 \%)$ & $1(3,45 \%)$ \\
\hline & & $\mathrm{K}$ & $3(20 \%)$ & $2(6,90 \%)$ \\
\hline \multirow{8}{*}{ Multimodal } & Bimodal & VA & $o(9 \%)$ & $2(6,90 \%)$ \\
\hline & & $\mathrm{AR}$ & $O(4 \%)$ & $1(3,45 \%)$ \\
\hline & & $\mathrm{AK}$ & $1(6,67 \%)$ & $6(20,69 \%)$ \\
\hline & Trimodal & VAR & $1(6,67 \%)$ & $1(3,45 \%)$ \\
\hline & & VAK & $1(6,67 \%)$ & $1(3,45 \%)$ \\
\hline & & ARK & $3(20 \%)$ & $5(17,24 \%)$ \\
\hline & Quadmodal & VARK & $2(13,33 \%)$ & $6(20,69 \%)$ \\
\hline & & Jumlah & $15(100 \%)$ & $29(100 \%)$ \\
\hline
\end{tabular}

Secara umum menunjukkan bahwa pada unimodal laki-laki memiliki kecenderungan gaya belajar visual (V) dan kinestetik (K), sedangkan perempuan memiliki kecenderungan gaya belajar audio (A). Pada multimodal, laki-laki memiliki kecenderungan gaya belajar trimodal (ARK) 
sedangkan perempuan memiliki kecenderungan gaya belajar bimodal (AK) dan quadmoadal (VARK). Adapun preferensi gaya belajar unimodal, bimodal, trimodal dan quadmodal mahasiswa berdasarkan jenis kelamin diberikan pada Gambar 2.

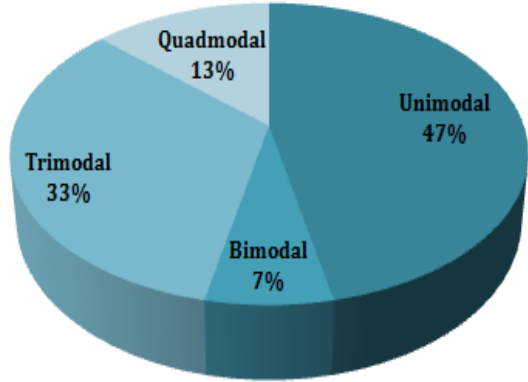

(a)

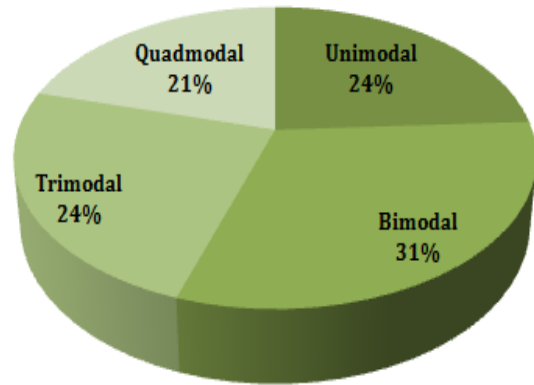

(b)

\section{Gambar 2.Distribusi gaya belajar mahasiswa (a) laki-laki (b) perempuan}

Gambar 2 menunjukkan bahwa sebagian besar laki-laki lebih memiliki respon terhadap pembelajaran unimodal, sedangkan perempuan pembelajaran bimodal. Secara umum, 47\% perempuan menyukai bentuk unimodal dan $53 \%$ menyukai multimodal ( $7 \%$ bimodal, $33 \%$ trimodal dan $13 \%$ quadmodal). Sedangkan $24 \%$ laki-laki lebih menyukai unimodal dan $76 \%$ menyukai multimodal ( $31 \%$ bimodal, $24 \%$ trimodal dan $21 \%$ quadmodal). Artinya laki-laki memiliki kecenderungan multimodal dan perempuan memiliki kecenderungan multimodal. Hal ini sejalan dengan penelitian Sulistyanto \& Nurgiyatna (2019)bahwa perbedaan gender dalam program studi yang sama tidak memiliki pengaruh signifikan pada jenis gaya belajar. Begitu pula penelitian Damayanti \& Pratitis (2012) bahwa tidak ada perbedaan yang signifikan antara gaya belajar ditinjau dari jenis kelamin pada mahasiswa. Artinya mahasiswa laki-laki dan perempuan memiliki kecenderungan yang sama dalam gaya belajarnya.

Secara keseluruhan baik ditinjau berdasarkan kelas dan jenis kelamin, modalitas mahasiswa angkatan 2017 Prodi Pendidikan Matematika adalah multimodal. Hal ini disebabkan oleh perbedaan karakteristik gaya belajar yang dimiliki oleh peserta didik yang satu dengan yang lainnya. Titin(2018) menyatakan bahwa kecenderungan belajar peserta didik sangat bervariasi, begitu pula dengan modalitas belajar serta cara untuk menerima informasi yang diperoleh dari proses pembelajaran pada setiap peserta didik memiliki bentuk yang bervariasi. Dengan adanya informasi gaya belajar mahasiswa ini, dapat membantu dosen dalam memilih model/metode pembelajaran yang inovatif, efektif dan efisien dalam memfasilitasi pemahaman mahasiswa terhadap materi perkuliahan guna meningkatkan prestasi akademiknya. Suatu model pembelajaran yang tepat dan sesuai dengan karakteristik juga keadaan kelas dapat memfasiltasi peran aktif semua siswa dalam aktivitas pembelajaran. Peranan tersebut diharapkan dapat menghasilkan peserta didik yang berkualitas sesuai dengan bakat dan minat, serta kondisi lingkungannya. Hal ini sejalan dengan pendapat Safitri et al.(2020), bahwa gaya belajar merupakan kunci untuk mengembangkan kinerja di sekolah maupun di linkungan individu. Ketika bisa menyadari bagaimana menyerap informasi kemudian mampu mengolah dengan baik, maka dapat menjadikan belajar menjadi lebih mudah.Wahyuddin (2016) mengungkapkan bahwa gaya belajar mahasiswa yang beragam dapat diatasi dengan perubahan metode dan penggunaan multimedia. Oleh karena itu, pendidiksenantiasa menggunakan metode dan media pembelajaran yang inovatif dan bervariasi sehingga materi pembelajaran dapat dipahami oleh seluruh peserta didik yang memiliki gaya belajar berbeda-beda.

\section{SIMPULAN}

Gaya belajar mahasiswa angkatan 2017 Prodi Pendidikan Matematika USN Kolaka mempunyai kecenderungan multimodal dan menunjukkan bahwa tidak terdapat perbedaan gaya belajar mahasiswa baik ditinjau dari perbedaan kelas ataupun jenis kelamin. Melalui identifikasi dan analisis gaya belajar mahasiswa ini, dosen dapat mengembangkan dan menggunakan pendekatan 
pembelajaran yang sesuai dengan materi dan gaya belajar mahasiswa. Kegiatan yang dapat dilakukan untuk untuk menyesuaikan dengan semua tipe gaya belajar adalah mengkombinasikan model atau metode pembelajaran seperti belajar kelompok, flipped classroom, gamification, problem based learning, contextual teaching learning dan sebagainya. Selain itu penggunaan media pembelajaran juga disesuaikan misal melalui pengggunaan aplikasi-aplikasi pembelajaran berupa matlab, geogebra, spss, atau membuat video-video pembelajaran yang sesuai dengan materi pembelajaran. Kesesuaian antara gaya belajar, model pembelajaran dan penggunaan media menentukan keberhasilan proses pembelajaran disetiap kelas. Melalui penyesuaian ini akan menciptakan lingkungan belajar yang efisiendan memotivasi siswa untuk mencapai keberhasilan akademis. Pemahaman gaya belajar peserta didik dapat memberikan informasi yang berguna bagi pendidik. Pendidik hendaknya tidak berasumsi bahwa semua siswa memiliki gaya belajar yang sama. Pembelajaran dengan berbagai metode dapat membantu mencapai keragaman peserta didik. Dengan demikian perlu memahami gaya belajar untuk menentukan strategi pembelajaran yang tepat. Penelitian selanjutnya dapat memanfaatkan informasi gaya belajar mengajar ini sebagai bentuk pengembangan model pembelajaran yang dapat memfasilitasi gaya belajar peserta didik secara keseluruhan. Peneliti lain dapat mengkaji keefektifan pengembangan model pembelajaran yang sesuai dengan gaya belajar peserta didik.

\section{DAFTAR PUSTAKA}

Chairuddin, C., \& Farman, F. (2019). Comparison of The Effectiveness of Scientific Approach and Problem-Solving Approach in Problem-Based Learning in Class IX of SMP Negeri 3 Pangsid. $\begin{array}{llll}\text { Journal of } & \text { Mathematics }\end{array}$ https://doi.org/10.31327/jomedu.v4i2.1010

Choudhary, R., Dullo, P., \& Tandon, R. (2011). Gender Differences In Learning Style Preferences Of First Year Medical Students. Pak $J$ Physiol, 7(2), 4. http://pps.org.pk/PJP/72/Raghuveer.pdf

Damayanti, A. K. \& Pratitis, Niken Titi. (2012). Gaya Belajar Ditinjau dari Tipe Kepribadian dan Jenis Kelamin. Persona:Jurnal Psikologi Indonesia, 1(2). https://doi.org/10.30996/persona.vii2.33

Farman, F. (2020). Development of Mathematics Learning Design through Problem Posing Approach for Developing Mathematical Reasoning Ability. Proceeding of USN Kolaka-ADRI International Conference on Sustainable Coastal-Community Development, 1(0), 167-174. https://doi.org/10.31327/icusn-adri.viio.1158

Güryay, B. (2016). The Relationship between Learning Modalities and Perceived Self-regulation Levels. Procedia - Social and Behavioral Sciences, 232, 389-395. https://doi.org/10.1016/j.sbspro.2016.10.054

Hali, F., Ramlan, A. M., \& Farman. (2020). Improving Learning Outcomes of Mathematics Students In Polynomial Topic Through The Reciprocal Teaching Approach In Class XI IA1 SMAN 2 Kendari. Proceeding of USN Kolaka-ADRI International Conference on Sustainable Coastal-Community Development, 1, 4.https://doi.org/10.31327/icusn-adri.v1io.1142

Jahring, J., \& Chairuddin, C. (2019). Preferensi Modalitas Belajar Mahasiswa Angkatan 2016 Program Studi Pendidikan Matematika Universitas Sembilanbelas November Kolaka. Square: Journal of Mathematics and Mathematics Education, 1(1), 27-32. https://doi.org/10.21580/square.2019.1.1.4039

Karim, M. R., Asaduzzaman, A., Talukder, M. H. K., Alam, K. K., Haque, F., \& Khan, S. J. (2019). Learning Style Preferences Among Undergraduate Medical Students: An Experience from Different Medical Colleges of Bangladesh. Bangladesh Journal of Medical Education, 1O(2), 26-30. https://doi.org/10.3329/bjme.v10i2.44640

Lisiswanti, R. (2014). The Relation Ship Learning Styles And Student's Achievement Of Lampung $\begin{array}{lllll}\text { University Faculty Of } & \text { Medicine. }\end{array}$ http://juke.kedokteran.unila.ac.id/index.php/juke/article/view/383

Marzo, R. R. (2016). Learning Style Preferences Among Medical Students in Malaysian Medical Universities. Texila International Journal of Public Health,4(1), 121-131. https://doi.org/10.21522/TIJPH.2013.04.01.Artoo9 
Mulyadi, M. (2011). Penelitian Kuantitatif dan Kualitatif Serta Pemikiran Dasar Menggabungkannya.Jurnal Studi Komunikasi dan Media, 15 (1). http://dx.doi.org/10.31445/jskm.2011.150106

Rahmawati, E., Saputra, O., \& Saftarina, F. (2018). Hubungan Gaya Belajar terhadap Indeks Prestasi Kumulatif (IPK) Mahasiswa Fakultas Kedokteran Universitas Lampung. Medula, 8(1), 5. https://juke.kedokteran.unila.ac.id/index.php/medula/article/view/2035

Safitri, N., Hartatik, S., Nafiah, N., \& Hidayat, M. T. (2020). Visual students skill in drawing two dimensional imaginatif. Al-ishlah: Jurnal Pendidikan, 12(2), 398-412. https://doi.org/10.35445/alishlah.v12i2.216

Sari, A. K. (2014). Analisis Karakteristik Gaya Belajar VAK(Visual, Auditorial, Kinestetik)Mahasiswa Pendidikan Informatika Angkatan 2014. Edutic - Scientific Journal of Informatics Education, 1(1). https://doi.org/10.21107/edutic.v1i1.395

Sinha, N., Bhardwaj, A., Singh, S., \& Abas, A. (2013). Learning Preferences Of Clinical Students: A Study In A Malaysian Medical College. International Journal of Medicine and Public Health, 3(1), 6o. https://doi.org/10.4103/2230-8598.109325

Stephenson, S. S. (2019). Learning Styles Assessment Modalities Preferences Diagnostics (Lamp-D): A Framework Of Accounting Students' Preferred Learning Styles And Course Learning Assessments. The Accounting Educators' Journal, 29(1). https://aejournal.com/ojs/index.php/aej/article/view/593

Sulisawati, D. N., Lutfiyah, L., \& Sukma, L. (2019). Identifikasi Modalitas Belajar Vak Kombinasi Siswa Dalam Pelajaran Matematika SMP Negeri 1 Arjasa Jember. Prismatika: Jurnal $\begin{array}{llll}\text { Pendidikan dan } \text { Riset } & \text { 2(1), }\end{array}$ https://doi.org/10.33503/prismatika.v2i1.572

Sulistyanto, H. \& Nurgiyatna. (2019). Kajian Identifikasi Gaya Belajar Mahasiswa Berbasiskan Web Berdasarkan pada Disiplin Ilmu dan Gender. Proceeding of The 1oth University Research Colloquium 2019: Bidang Pendidikan, Humaniora dan Agama, 3053014.http://repository.urecol.org/index.php/proceeding/article/view/774

Titin, T. (2018). Profil Modalitas Belajar Mahasiswa Program Studi Pendidikan Biologi. Jurnal Pendidikan Informatika dan Sains, 7(2), 167. https://doi.org/10.31571/saintek.v7i2.1039

Urval, R. P., Kamath, A., Ullal, S., Shenoy, A. K., Shenoy, N., \& Udupa, L. A. (2014). Assessment of learning styles of undergraduate medical students using the VARK questionnaire and the influence of sex and academic performance. Advances in Physiology Education, 38(3), 216220. https://doi.org/10.1152/advan.00024.2014

Wahyuddin, W. (2016). Gaya Belajar Mahasiswa. ALQALAM, 33(1), 105-120. https://doi.org/10.32678/alqalam.v33i1.387

Wehrwein, E. A., Lujan, H. L., \& DiCarlo, S. E. (2007). Gender differences in learning style preferences among undergraduate physiology students. Advances in Physiology Education, 31(2), 153-157. https://doi.org/10.1152/advan.ooo6o.2006. 